\title{
THE ELUSIVE SEARCH FOR ACCOUNTABILITY: EVALUATING ADJUDICATIVE TRIBUNALS ${ }^{ \pm}$
}

\author{
Lorne Sossin* \\ Steven J. Hoffman**
}

Evaluating the success of adjudicative tribunals is an important but elusive undertaking. Adjudicative tribunals are created by governments and given statutory authority by legislatures for a host of reasons. These reasons may and often do include legal aspects, policy aspects and partisan aspects. While such tribunals are increasingly being asked by governments to be accountable, too often this devolves into publishing statistics on their caseload, dispositions, budgets and staffing. We are interested in a different and more basic question - are these tribunals successful? How do we know, for example, whether the remedies ordered by a tribunal actually do advance the purposes for which it was created? Can the success of an adjudicative tribunal be subject to meaningul empirical validation? While issues of evaluation and accountability cut across national and jurisdictional boundaries, the authors argue that this type of question can only be addressed empirically, by actually looking to the practice of a particular board or boards, in the context of a particular statute or statutes, and in particular jurisdictions at particular times. Such accounts can and should form the basis for comparative study. Only through comparative study can the value and limitations of particular methodologies become apparent. This study takes as its case study the role of adjudicative tribunals in the health system. The authors draw primarily from Canadian tribunal experience, though examples from other jurisdictions are used to demonstrate the potential of empirical evaluation. The authors discuss the relative dearth of empirical study in administrative law and argue that it ought to be the focus of the discussion on accountability in administrative justice.

Évaluer le succès de tribunaux qui tranchent des litiges est une entreprise importante mais difficile à effectuer. Les tribunaux qui tranchent des litiges sont créés par des gouvernements et dotés de pouvoir légal par des législatures pour une multitude de raisons. Ces raisons peuvent inclure des aspects légaux, des aspects liés à des politiques et des aspects partisans ce qui est souvent le cas. Quoique les gouvernements demandent de plus en plus à de tels tribunaux de

\pm This paper was originally prepared for the Sixth Administrative Law Discussion Forum, Québec City, May 25-26, 2010. The analysis paper builds on "Evaluating the Impact of Remedial Authority: Adjudicative Tribunals in the Health Sector," which was presented at the CIAJ Conference, "Taking Remedies Seriously," October 30, 2009. We have also benefited from the discussion arising from the Workshop on the Impact of Health Tribunals that was held at the University of Toronto's Faculty of Law on 28 May 2009 and funded by the Canadian Institutes of Health Research.

* Dean \& Professor, Osgoode Hall Law School, York University. Sossin is a Vice-Chair of the Health Professions Appeals and Review Board and the Health Services Appeal and Review Board, which are discussed in this paper. The views expressed in this paper are his alone and do not necessarily reflect the views of either Board.

** Adjunct Professor, Faculty of Health Sciences, McMaster University, Hamilton, Ontario, Canada, and Fellow, Munk School of Global Affairs, University of Toronto, Ontario, Canada. 
rendre compte, trop souvent, ceci se réduit à la publication de statistiques sur le nombre de cas traités, leurs dispositions, les budgets et le personnel. Une question différente et plus fondamentale nous intéresse - ces tribunaux réussissent-ils? Comment savons-nous, par exemple, si les recours ordonnés par un tribunal font en fait avancer les objectifs pour lesquels il a été créé? Le succès d'un tribunal qui tranche des litiges peut-il faire l'objet de validation empirique signifiante? Quoique les questions d'évaluation et du devoir de rendre compte traversent des frontières entre nations et champs de compétence, les auteurs soutiennent que ce genre de question ne peut être traité qu'empiriquement, en examinant en fait les pratiques d'un conseil ou de conseils particuliers, dans le contexte d'une loi ou de lois particulières et dans des sphères de compétence particulières à des moments particuliers. De tels comptes rendus peuvent et devraient constituer la base d'étude comparative. Seule l'étude comparative peut faire ressortir la valeur et les limites d'une méthodologie particulière. L'étude de cas choisie pour la présente étude est le rôle de tribunaux qui tranchent des litiges dans le système de santé. Les auteurs puisent surtout dans l'expérience de tribunaux canadiens, quoique des exemples tirés d'autres territoires de compétence soient utilisés pour démontrer le potentiel de l'évaluation empirique. Les auteurs discutent de la pénurie relative d'étude empirique dans le domaine du droit administratif et soutiennent que là devrait être le point central de la discussion du devoir de rendre compte dans le domaine de la justice administrative.

\section{INTRODUCTION}

Evaluating the success of adjudicative tribunals, like accountability itself, is an important but elusive undertaking. Adjudicative tribunals are created by governments and given statutory authority by legislatures for a host of reasons. These reasons may and often do include legal aspects, policy aspects and partisan aspects. While such tribunals are increasingly being asked by governments to be accountable, too often this devolves into publishing statistics on their caseload, dispositions, budgets and staffing. We are interested in a different and more basic question - are these tribunals successful? How do we know, for example, whether the remedies ordered by a tribunal actually do advance the purposes for which it was created? Can the success of an adjudicative tribunal be subject to meaningful empirical validation? This is the question we attempt to explore.

While issues of evaluation and accountability cut across national and jurisdictional boundaries, we believe this question can only be addressed by looking to the practice of a particular board or boards, in the context of a particular statute or statutes, and in particular jurisdictions. Such accounts can (and, in our view, should) then form the basis for comparative study. Only through comparative study can the value and limitations of particular methodologies become apparent.

See for e.g. the paper presented by Laverne Jacobs on the new Ontario tribunal legislation for the Administrative Law Discussion Forum (Quebec City) (May 25-26, 2010), “A Wavering Commitment? Administrative Independence and Collaborative Governance in Ontario's Adjudicative Tribunals Accountability Legislation" (2010) 26:2 Windsor YB Access Just. 
This study takes as its case study the role of adjudicative tribunals in the health system, but the concern for evaluation could be applied just as easily to a variety of administrative, policy or operational spheres. While we draw primarily from Canadian tribunal experience, the literature in this field is primarily American, British and Australian. Not only does this literature derive from several jurisdictions, it also is as likely to arise from sociologists, political scientists and health policy experts as from lawyers and legal scholars. Our hope is that this brief analysis stimulates discussion across both academic and national boundaries, and specifically within the administrative law community.

Adjudicative tribunals were established in order to play an important role in the health sector, yet their actual influence as part of the health system remains largely unknown. ${ }^{2}$ Most evaluations of their work have focused on internal measures of accountability and independence rather than external indicators of societal impact. When their effectiveness is examined, evaluators tend to utilize anecdotes from various experts and stakeholders rather than rigorous empirical data. As efforts to reform health systems continue both within Canada and internationally, it will be increasingly important to understand the benefits, costs and implications of adjudicative tribunals for providers and consumers of health care services as well as the institutional structures on which they rely.

In this context, empirical evaluations represent an opportunity to inform policymaking through better understanding the impact of adjudicative tribunals on the health system. Empirical research includes quantitative and qualitative investigations on the effects of tribunal processes and decision-making on economic, social or health outcomes. ${ }^{3}$ Empirical study designs range from experimental (e.g., randomized controlled trials, interrupted time-series studies, etc.) to observational (e.g., cohort, case-control and cross-sectional studies), with data often gathered from surveys, interviews, focus groups, statistical inventories, performance data or documentary analyses.

Empirical research certainly is not new to the health sphere but it is less common in adjudicative settings and rarer still in the context of administrative justice. That said, interest in empirical research in this aspect of the health system is on the rise. ${ }^{4}$ In addition to these general challenges faced by all empirical legal researchers, any attempt to evaluate the impact of a health-related adjudicative tribunal faces additional hurdles. Not only has such an assessment never before been comprehensively undertaken, but the most suitable research methodology to do so remains highly elusive. Much of empirical health research, for example, relates to patient outcomes and the costs associated with achieving these outcomes. In the setting of adjudicative tribunals, these metrics may not apply. A proceeding before a health tribunal may take place after the outcome for the patient already has occurred,

2 Adjudicative tribunals may be defined in a number of ways. This category could include: (1) any administrative body engaged in adjudication, including regulatory bodies whose principle function is policymaking but who also engage in adjudication; (2) both administrative and judicial bodies which engage in adjudication; or (3) only those bodies whose primary or only function is adjudication. R. Ellis, Executive Branch Justice: Canada's “Official Courts” (Ph.D. Dissertation, Osgoode Hall Law School, York University, 2009) [unpublished] at 77.

3 M.M. Mello \& K. Zeiler, "Empirical Health Law Scholarship: The State of the Field" (2008) 96 Geo. LJ 649.

$4 \quad$ Ibid. 
or at a time when the outcome is unlikely to have any impact on patient outcome. For this reason, the tribunals in fact may impose additional costs on the health system without directly yielding improved health outcomes. While those additional costs may well lead to better practices and procedures on the part of other actors in the health system (e.g., regulatory colleges, insurance plans, hospitals), or enhance public confidence in the accountability of the health system, this type of benefit is indirect, may only become apparent over time, and is inherently difficult to measure.

Distinctions in statutory mandate and the absence of clear statutory language setting out the purposes of adjudicative tribunals may leave no final target outcomes against which services can be evaluated. Further, as creatures of statute that serve quasi-judicial functions, adjudicative tribunals sit at the intersection of the legal and health worlds. These tribunals operate within these two paradigms - a dichotomy of process and outcomes - whose goals may sometimes diverge. Indeed, these administrative bodies are expected to preserve the legal focus on process, fairness and individual-level dispute resolution while at the same time working to improve healthrelated outcomes by enhancing the overall effectiveness of the health system. ${ }^{5}$ The tension between a process and a substance based mandate presents distinct challenges for empirical evaluation. The complex co-dependence and interconnectedness of these tribunals with the health system's constituent elements ensure that simple appraisal techniques cannot be effectively utilized. To the extent that adjudicative tribunals have an impact on the health system, it is likely to be linked to a host of other variables. The fact that evaluation is not easy, however, does not detract from its importance.

Despite these benefits, the evaluation and accountability of adjudicative tribunals is one of the least scrutinized areas of administrative law. ${ }^{6}$ The topic necessarily engages the issue of administrative independence, the statutory environment within which all adjudicative tribunals operate, the policy priorities of government which fund tribunals, the complexity of the health system, and the role of the court in supervising health-related adjudicative tribunals through the mechanisms of judicial review. Evaluating impact in the health sector is also necessarily a contextual exercise. As Peter Cane observed in the administrative law context, "the impact of judicial review needs to be studied in a contextualised way by reference to judicial review's objectives and functions. Also, it should not be assumed that, when we discuss the impact of judicial review, we are all talking about impact of the same thing or, at least, of a single institution with a single set of objectives and functions." $\mathrm{A}$ similar approach is necessary for health-related adjudicative tribunals but has never been systematically followed.

$5 \quad$ While this process-outcomes dichotomy between the legal and health worlds is certainly evident when comparing their respective research literature, it is important to recognize that both types of work are conducted within both realms. Mello and Zeiler, ibid. for example, highlight several socio-legal studies that gathered outcome-related data, and health researchers frequently address questions of ethics and resource allocation that are more procedural in nature.

6 See the discussion of the study of tribunals in Peter Cane, Administrative Tribunals and Adjudication (London: Hart, 2009), ch. 1

$7 \quad$ Ibid. M. Sunkin, "Conceptual Issues in Researching the Impact of Judicial Review on Government Bureaucracies" in M. Hertogh \& S. Halliday, eds, Judicial Review and Bureaucratic Impact: International and Interdisciplinary Perspectives (Cambridge, UK: Cambridge University Press, 2004) 43. 
This paper aims to explore the context, challenges and opportunities for empirically evaluating the impact of adjudicative tribunals in the health sector. First, we discuss the purpose, function and importance of these bodies within the health system, including their statutory mandates and policy goals. Second, we examine the various ways in which their performance could potentially be assessed and will justify why there is a need to develop empirical approaches for the assessment of adjudicative decision-making. Third, we identify the barriers to evaluating the impact of adjudicative tribunals. Finally, based on this analysis, we explore the path forward for the empirical assessment of adjudicative decision-making.

The focus of this analysis is on Ontario's two adjudicative health tribunals in Canada, the Ontario Health Professions Appeal and Review Board [HPARB] and the Health Services Appeal and Review Board [HSARB]. Both HPARB and HSARB have statutory mandates to review important health decisions that intimately affect the lives of their constituents. Using these two bodies as case studies for exploring the context, challenges and opportunities for evaluating adjudicative tribunals may enrich our understanding of administrative tribunals throughout other sectors as well.

\section{THE CONTEXT OF ADJUDICATIVE TRIBUNALS IN THE HEALTH SECTOR}

Adjudicative tribunals are administrative bodies that are created by statutes and exercise delegated decision-making powers of the executive branch for the purposes of achieving certain policy goals. They serve as an oversight mechanism for lowerlevel decision-makers and apply legal and normative principles to resolve disputes between conflicting parties. They are independent - operating at arm's-length from the government - and serve quasi-judicial functions otherwise fulfilled by the formal judicial system. This independence, however, also has limits; their members are appointed by the executive branch of government (in the case of HPARB and HSARB, the power of appointment is effectively in the hands of the Minister of Health, in consultation with the Chair of the Boards) which also sets their staffing allowances and budgets. Their decisions, while often final, must be authorized by their enabling statute and are subject to judicial review by the courts.

In the health sector, adjudicative tribunals may be involved with resolving disputes regarding medical malpractice claims, insurance coverage for health care services, determination of mental capacity, licensing decisions for health care facilities, and patient safety procedures. They serve as an oversight and accountability mechanism for lower-level health decision-makers and ensure they follow appropriate processes and act according to their respective statutory mandates. They aim to boost public confidence in the credibility of decision-making within the health system, facilitate better and more consistent decisions, and reduce the risk of errors that in this context can have deadly consequences. Finally, they promote fairness and justice within health care, militate against self-interest and corruption, and provide opportunities to address wrongs through redress.

The HPARB, for example, is an integral part of Ontario's self-regulating health professional system. It helps to ensure that the health professions are regulated in the public interest, that appropriate standards of practice are created and maintained, that patients have access to the health professional of their choice, and that they are treated with respect and sensitivity by health professionals. HPARB was established 
as a response to two related phenomena in the early 1970's: first, the recommendation arising out of the Report by the Honourable James Chalmers McRuer's Royal Commission Inquiry into Civil Rights ${ }^{8}$ [McRuer Report] which emphasized the need for public interest oversight over self-regulating professional bodies; and second, the Committee on the Healing Arts tabled by the government on April 28, $1970^{\circ}$ [Healing Arts Report], which also emphasized the primacy of public interest regulation of health professionals. Under the Province of Ontario's Regulated Health Professions Act [RHPA] people may appeal the decision of a self-regulated health professional College to not pursue a disciplinary proceeding before the HPARB. ${ }^{10}$ If the appropriate statutory processes were not followed by the relevant College, then the Board is empowered to send the matter back to the college for reconsideration. HPARB also hears appeals from adverse decisions by the colleges in relation to registration requests. The remedies available to HPARB panels focus on the regulated Colleges, as opposed to the parties. For example, if a complaint was dismissed and an HPARB panel finds that the investigation was inadequate or the decision to dismiss the complaint was unreasonable, the complaint usually will be sent back to the College to reconsider its reasons or investigate the complaint further. Recommendations to the College may also be provided where the issues raised on a complaint review are more systemic. Parties, however, are not entitled to damages, or to an apology, or to any other individual remedy they may seek or to which they may feel entitled. For this reason, it is not uncommon to find parties who both seek a complaint review from HPARB and simultaneously pursue civil remedies against health professionals or health facilities arising from the same factual circumstances.

The HSARB similarly is a part-time Board providing oversight for the decisions of various actors within the health system. Its broad jurisdiction arises from fourteen different statutes and includes reviewing decisions concerning payment for health care services under the Ontario Health Insurance Plan [OHIP], eligibility for housing in long-term care facilities, licensing of nursing homes and other independent health facilities, and the decisions of public health officials. ${ }^{11}$ By contrast, HSARB provides individual remedies, ordering, for example, that OHIP fund out-of-country medical services where the statutory test is met.

Both HPARB and HSARB have a full-time Chair, ${ }^{12}$ and a roster of part-time members, ${ }^{13}$ some of whom have legal training (and, in the case of HSARB, legal or medical training) and some who do not. Both Boards have been held to be expert

8 Royal Commission Inquiry into Civil Rights, (Toronto: Queen's Printer, Ontario, 1968) (Commissioner: Honourable J.C.McRuer).

9 Report of the Committee on the Healing Arts, (Toronto: Queen's Printer, 1970) (Chair: I. R. Dowie)

10 Regulated Health Professions Act, 1991, S.O. 1991, c. 18, s. 3. Also see R. Steinecke. A Complete Guide to the Regulated Health Professions Act, looseleaf. (Toronto: Canada Law Book, 2000). The RHPA is one of several statutes administered by HPARB.

11 C. Pitfield \& C.M. Flood, "Section 7 'Safety Valves': Appealing Wait Times Within a One-Tier System" in C.M. Flood, K. Roach \& L. Sossin, eds, Access to Care, Access to Justice: The Legal Debate Over Private Health Insurance in Canada (Toronto: University of Toronto Press, 2005) 477.

12 Since 2008, the same individual has served as Chair of both Boards.

13 HPARB has three full time Vice Chairs and approximately 35 part-time members. HSARB has approximately 25 part-time members. Of these, approximately 10 part-time members are crossappointed to both Boards. 
bodies by reviewing Courts which warrant deference. Their substantive decisions may only be overturned on judicial review to a court if found to be "unreasonable." ${ }^{14}$

As indicated above, a key aspect of evaluating tribunals created by statute is to assess whether a tribunal is fulfilling its statutory objective(s). This may be especially challenging, for example, if the specific goals of the relevant tribunal are diffuse and ambiguous in their enabling legislation. Ontario's RHP $A$, for example, does not detail the purposes of the Board, so this must be inferred from the powers and authority it has been provided. For example, as indicated above, HPARB has the power to review decisions of regulated health colleges, not to refer complaints to discipline on grounds of the reasonableness of the college's decision and the adequacy of the college's investigation. ${ }^{15}$ HPARB has broader jurisdiction to review decisions by Colleges to deny registration to applicants. ${ }^{16}$ Thus, while HPARB's role is generally to ensure public interest accountability over decision-making by regulated health Colleges, HPARB's role in reviewing complaints suggests a different purpose, and a more deferential standard of review, than its role in reviewing denials of registration. Evaluation needs to be responsive to these differences of statutory mandate and remedial discretion.

\section{THE CONTEXT FOR EVALUATING ADJUDICATIVE TRIBUNALS}

Assessing the work of these adjudicative tribunals, as suggested above, is an inherently complex enterprise. However, evaluations can be thought of and categorized according to their orientation and methodology.

In terms of orientation, evaluations of tribunals can be focused on how they function or what impact they have. The former would analyze the internal operations of a tribunal while the latter would assess the body's external effects on a specified population. Procedural analyses are important to promote coherent internal management structures, good governance, accountability, efficiency and efficacy. External impact evaluations, on the other hand, represent a way to assess the realworld effectiveness of the adjudicative tribunal, its impact on others within the health care system, and the benefits (or consequences) that this impact yields. Such studies can determine whether or not these bodies support and/or enhance the functioning of various health system institutions and decision-makers and whether or not they ultimately influence service provision, access to justice in the health sector, and health outcomes. External impact evaluations require expertise and independence - they are not traditionally conducted by auditors, ${ }^{17}$ ombudsmen ${ }^{18}$ or internal staff. ${ }^{19}$

14 See, with respect to HPARB, Botros v. Beadle (2007), 71 Admin LR (4th) 225, and with respect to HSARB, Flora v. Ontario (Health Insurance Plan, General Manager) 2008 ONCA 538.

15 See s. 29(2) of the Health Professions Procedure Code, Schedule 2 to the RHPA.

16 See s. 22(1) of the Health Professions Procedure Code, Schedule 2 to the RHPA.

17 Ontario, Office of the Auditor-General (J. McCarter), Annual Report 2008 (Toronto: Queen's Printer for Ontario, 2008) online: Government of Ontario <http://www.auditor.on.ca/en/reports_en/en08/ar_en08.pdf $>$ ).

18 Ontario, Office of the Ombudsman, Ombudsman Ontario: Annual Report 2007-2008, (Chair: A. Marin) online: Ombudsman Ontario <http://www.ombuds-man.on.ca/media/18971/ar08_eng.pdf>.

19 Ontario, Health Professions Regulatory Advisory Council, HPRAC: Annual Report April 1, 2007 March 31, 2008. Online: HPRAC <http://www.h-p-r-a-c.org/en/reports/resources/H-P-R-A-CAnnual-Report-2007-2008.pdf $>$. 
A review of several evaluations of administrative bodies highlights that they tend to focus on issues related to internal operations rather than external impact. The recent report of the Ontario Security Commission's Fairness Committee, for example, examined whether the agency's internal governance structure created a perception or reality of bias in its adjudicative responsibilities ${ }^{20}$. The United Kingdom's National Audit Office similarly reviewed the procedures used by its Department of Work and Pensions to medically assess incapacity and disability ${ }^{21}$ and to hear appeals of social security benefit decisions. ${ }^{22}$ Some reviews examine particular problems that had previously been identified ${ }^{23}$ while others focus on users' satisfaction with a tribunal's provision of services. ${ }^{24}$

Several assessment efforts have even focused on the internal operations of multiple tribunals or a jurisdiction's entire tribunal system, including the report of Ontario's Agency Reform Commission, ${ }^{25}$ the UK's Leggatt Review of Tribunals, ${ }^{26}$ and the report of the UK's former Council on Tribunals ${ }^{27}$. Academic publications similarly

20 Ontario, Ontario Securities Commission Report of the Fairness Committee to David A. Brown, Q.C., Chair of the Ontario Securities Commission, 2004 (authors, C.A. Osborne, D.J. Mullan, and B. Finlay). Online: OSC<http://www.osc.gov.on.ca/Regulation/Five-Year-Review/fyr_2004-0818_fairness committee.pdf $>$.[ Osborne Report]

21 United Kingdom, National Audit Office, Progress in Improving the Medical Assessment of Incapacity and Disability Benefits: Report by the Comptroller and Auditor General. HC 1141, Session 2002-2003, 17/10/2003. (London: Stationery Office, 2003) online: NAO < http://www.nao. org. uk/publications/ nao_reports/02-03/0203-1141.pdf $>$ [NAO Progress].

22 United Kingdom, National Audit Office, Getting It Right, Putting It Right: Improving Decision-Making and Appeals in Social Security Benefits. HC 1142, Session 2002-2003, 07/11/2003. (London: Stationery Office, 2003). Online: NAO < http://www.nao.org.uk/publications/nao_reports/02-03/02031142 .pdf $>[N A O$, Getting it Right $]$.

23 Ontario, Society of Ontario Adjudicators and Regulators, Towards Maintaining and Improving the Quality of Adjudication: SOAR Recommendations for Performance Management in Ontario's Administrative Justice Tribunals. (Toronto: Society of Ontario Adjudicators and Regulators, 1995), online: SOAR $<$ http://www.soar.on.ca/soar-perf_man.htm> [SOAR Recommendations]; S. Blumenthal \& S. Wessely, The Pattern of Delays in Mental Health Review Tribunals. (London: Stationery Office, 1993); S. Blumenthal \& S. Wessely, "The Pattern of Delays in Mental Health Review Tribunals" (1994) 18 Psychiatric Bulletin 400. Online: The Psychiatrist <http://pb.rcpsych.org/cgi/reprint/18/7/398.pdf>.

24 J. Aston, D. Hill \& N.D. Tackey, The Experience of Claimants in Race Discrimination Employment Tribunal Cases. Employment Relations Research Series, No. 55. (London: UK Department of Trade and Industry, 2006) online: DTI < http://www.dti.gov.uk/files/file27818.pdf>;Employment Tribunals Service, Employment Tribunals Service User Survey 2005 (London: Employment Tribunals Service, 2005); Confederation of British Industry, A Matter of Confidence: Restoring Faith in Employment Tribunals (London: Confederation of British Industry, 2005). Online: CBI < http://www.c-b- i.org.uk/n-d-bs/Press.nsf/0/33f-9830ed-75f765b-8025708-8005-23621/\$FILE/Tribunals-Brief-CBI.pdf>; M.P. Carscallen, W.K. Gray \& J.G. Pink, Regulatory Burden Task Force: Report to the Ontario Securities Commission (Toronto: Ontario Securities Commission, 2003) online: OSC < http://www.o-s- c.gov. on.ca/About/Governance/Accountability/ga_20031212_rbtf-rpt.pdf>.

25 Ontario, Agency Reform Commission on Ontario's Regulatory and Adjudicative Agencies (G. Guzzo, J. Baird, B. Grimmett, G. Martiniuk \& J. Flaherty) Everyday Justice: Report of the Agency Reform Commission on Ontario's Regulatory and Adjudicative Agencies. (Toronto: Government of Ontario, 1998). Online: Council of Canadian Administrative Tribunals < http://www.ccat- ctac.org/ downloads/ 1998_Guzzo-report.pdf> [Guzzo Report].

26 A. Leggatt, Tribunals for Users: One System, One Service (London: UK Department for Constitutional Affairs, 2001) online: <http://www.tribunals-review.org.uk/index.htm>.

27 M. Adler \& J. Gulland, Tribunal Users' Experiences, Perceptions and Expectations: A Literature Review (London: Council on Tribunals, 2003) online: Council on Tribunals<http://www.council- ontribunals.gov.uk/docs/other_adler(2).pdf $>$. 
appear to focus on the internal operations of tribunals across various topics whether they regulate securities, ${ }^{28}$ medical malpractice claims, ${ }^{29}$ privacy, ${ }^{30}$ pensions, ${ }^{31}$ or determinations of medical incapacity ${ }^{32}$ - and often examine users' experience. ${ }^{33}$ While not a single governmental evaluation could be found that focused on the external impact of adjudicative tribunals, at least one academic publication discusses the potential benefits that administrative "health courts" (which resolve malpractice claims) can have on patient safety.

In terms of methodology, assessments of tribunals can either be conducted through expert reviews or empirical evaluations. The first approach would take advantage of the personal experiences and perspective of an investigator (usually based on some combination of interviews and analysis of primary data and secondary literature) while the second approach attempts to attain more objective and generalizable data. Expert reviews often focus on identifying structural problems and recommending possible ways to overcome them. This approach is also more likely to have fewer costs and a faster completion timeline. Empirical evaluations of tribunals, by contrast, aspire to scientific methods and can be used to, inter alia, quantitatively or qualitatively assess impact, identify the factors that determine their successful operations, and track perceptions of them over time. These two methodological approaches cannot be completely dichotomized as experts often utilize empirical methods and even the most scientifically rigorous and objective evaluations must be interpreted by individuals through the lens of their expertise.

Reviews of adjudicative tribunals have been conducted using both expert and empirical methodologies. Prominent observers, academics and practitioners, for

28 S. Rousseau, The Québec Experience with an Independent Administrative Tribunal Specialized in Securities: A Study of the Bureau de décision et de révision en valeurs mobilières (Ottawa: Expert Panel on Securities Regulation, 2008) online: Groupe Experts<http://www.groupe-experts.ca/eng/reports/research -studies/quebec-independent-adjudicative-tribunal-rousseau.php>; P. Moyer, "The Regulation of Corporate Law by Securities Regulators: A Comparison of Ontario and the United States" (1997) 55 UT Fac L Rev 43.

29 G. Siegal, M.M. Mello \& D.M. Studdert, “Adjudicating Severe Birth Injury Claims in Florida and Virginia: The Experience of a Landmark Experiment in Personal Injury Compensation" (2008) 34 Am J L \& Med 489. Online: Harvard School of Public Health < http://www.hsph.harvard.edu /faculty/michelle-mello/files/FL-VA_PDF.pdf>.

30 L. Jacobs. "Reconciling Tribunal Independence and Expertise -- Empirical Observations" (Presented at The Future of Administrative Justice Symposium, University of Toronto, 18 January 2008) online: University of Toronto Faculty of Law <http://www.law.utoronto.ca/ documents/ conferences/adminjustice08_Jacobs.pdf $>$.

31 L. Sossin, "The Effectiveness and Efficiency of Pension Regulation in Ontario and in Comparative Perspective" (Toronto: Expert Commission on Pensions, 2007) online: Pension Review $<$ http://www.pension-review.on.ca/english/summaries/8Sossin.html >.

32 M. Dolan, R. Gibb \& P. Coorey, "Mental Health Review Tribunals: A Survey of Special Hospital Patients' Opinions" (1999) 10 Journal of Forensic Psychiatry 264; C. Bradley, M. Marshall \& D. Gath. "Why Do So Few Patients Appeal Against Detention Under the Mental Health Act?"(1995) 310 Brit Med J 364. Online: BMJ < http://www.b-m-j.com/cgi/content/full/310/6976/364>; J. Peay, Tribunals on Trial: A Study of Decision Making Under the Mental Health Act 1983 (Oxford: Clarendon Press, 1989).

33 H. Genn, B. Lever, L. Gray, and National Centre for Social Research, Tribunals for Diverse Users, 2006 Online: Department for Constitutional Affairs<http:// www.d-c-a.gov.uk/research/2006/01_2006. $\operatorname{pdf}>$.

34 M.M. Mello et al, “'Health Courts' and Accountability for Patient Safety” (2006) 84 Milbank Quarterly 459 . 
example, have assessed various tribunals' organizational structures ${ }^{35}$, efficiency, ${ }^{36}$ accessibility, ${ }^{37}$ independence, ${ }^{38}$ performance standards ${ }^{39}$ and overall effectiveness. ${ }^{40}$ Other reviews feature empirical elements such as (1) surveys that capture the perceived quality of services offered, ${ }^{41}$ stakeholder attitudes towards the tribunal, ${ }^{42}$ and the functioning of a certain process; ${ }^{43}$ (2) interviews that probe users' experiences with the tribunal, ${ }^{4}$ its perceived impartiality, ${ }^{45}$ and the effectiveness of a particular procedure; ${ }^{46}$ and (3) performance data and documentary analyses for examining key features of a tribunal's caseload ${ }^{47}$ and arrangements for how it makes appeal decisions. ${ }^{48}$

The challenge in evaluating health-related adjudicative tribunals, therefore, seems to lie at the intersection of orientation and methodology. Assessments of adjudicative tribunals have focused on both process and impact, and have been conducted using both expert reviews and empirical methods, yet not a single review could be found that empirically evaluated the external impact of an adjudicative tribunal, despite extensive searching. While this lack of research may indicate that such undertaking are not important, interesting or possible, the evidence suggests otherwise: the need for external impact evaluations is evident ${ }^{49}$ and such evaluations have been conducted

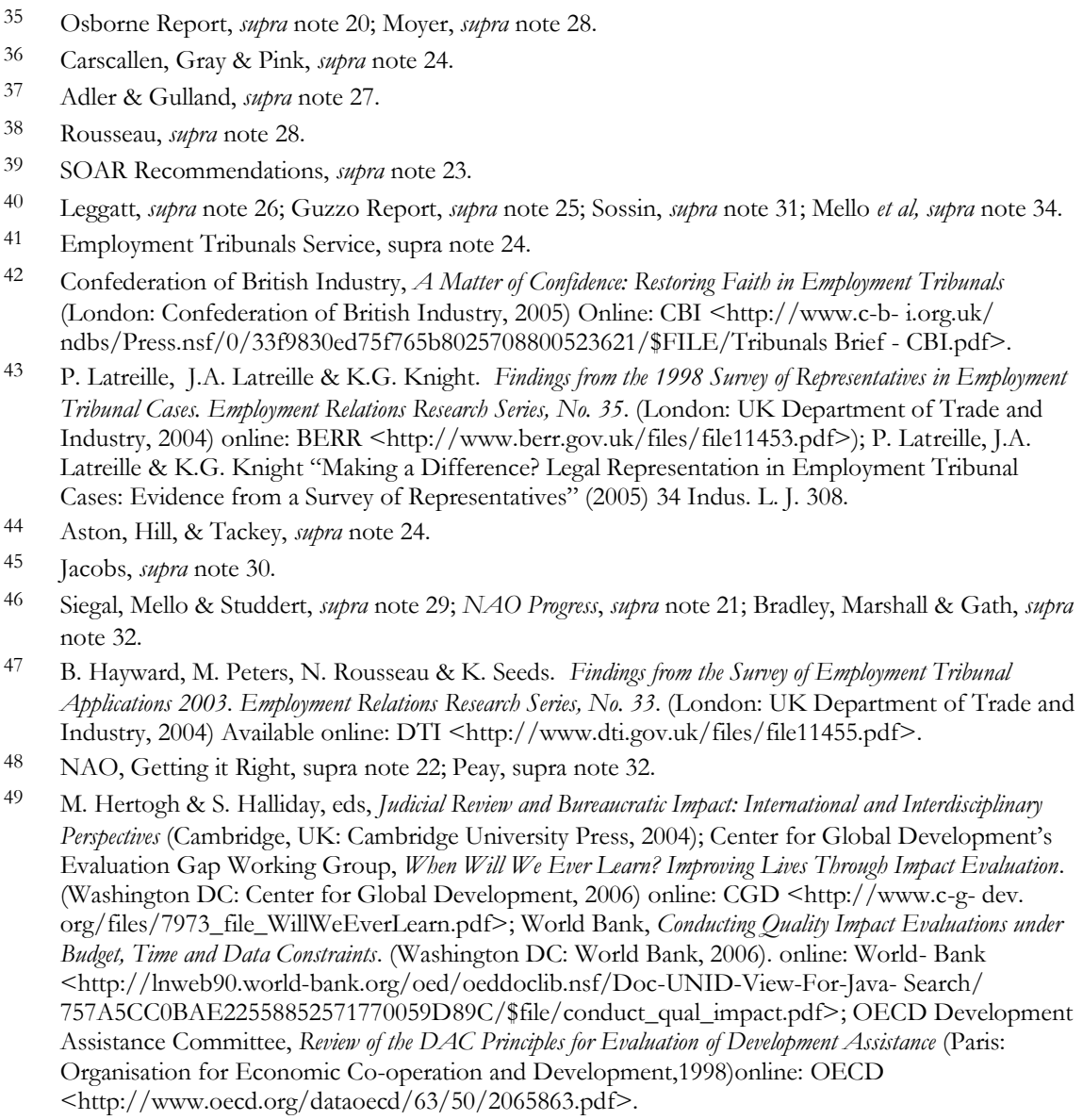

47 B. Hayward, M. Peters, N. Rousseau \& K. Seeds. Findings from the Survey of Employment Tribunal Applications 2003. Employment Relations Research Series, No. 33. (London: UK Department of Trade and Industry, 2004) Available online: DTI < http://www.dti.gov.uk/files/file11455.pdf>.

49 M. Hertogh \& S. Halliday, eds, Judicial Review and Bureaucratic Impact: International and Interdisciplinary Perspectives (Cambridge, UK: Cambridge University Press, 2004); Center for Global Development's Evaluation Gap Working Group, When Will We Ever Learn? Improving Lives Through Impact Evaluation. (Washington DC: Center for Global Development, 2006) online: CGD < http://www.c-g- dev. org/files/7973_file_WillWeEverLearn.pdf>; World Bank, Conducting Quality Impact Evaluations under Budget, Time and Data Constraints. (Washington DC: World Bank, 2006). online: World- Bank <http://lnweb90.world-bank.org/oed/oeddoclib.nsf/Doc-UNID-View-For-Java- Search/ 757A5CC0BAE22558852571770059D89C/\$file/conduct_qual_impact.pdf>; OECD Development Assistance Committee, Review of the DAC Principles for Evaluation of Development Assistance (Paris: Organisation for Economic Co-operation and Development,1998)online: OECD <http://www.oecd.org/dataoecd/63/50/2065863.pdf>. 
with success in related settings which also involve the nexus of the health and law sectors and beyond. ${ }^{50}$

The dearth of externally-focused empirical evaluations is not only a missed opportunity, in our view, but may also pose a significant risk. The lack of an empirical rationale for the benefits of a tribunal may render it vulnerable to opposition or simply to general cost-cutting initiatives, or to pursue policy directions that undermine rather than advance its purposes. Without this data, the Boards may lack the baseline measures needed to track changes over time, evaluate the performance of decision-makers and staff, and engage in longer term strategic planning. If you are running in the dark, there is no way to know whether you are moving forward, or further away from your destination, or simply going in circles.

Indeed, it is widely accepted that data-driven strategies are more likely to help decision-makers achieve their goals in a cost-effective way than polices pursued in the absence of evidence. ${ }^{51}$ Information gathered by health-related adjudicative tribunals like HPARB and HSARB through empirical methods may be of particular interest to government officials as it can demonstrate performance benchmarks and ensure public funds are being invested and spent effectively. If reform is called for, empirical data will be essential in identifying what needs to change. For academics, it is an under-scrutinized sphere of administrative law and health systems functioning that is both ripe for research and, potentially, reform.

\section{CHALLENGES FOR EMPIRICALLY EVALUATING ADJUDICATIVE TRIBUNALS}

Yet despite the tremendous benefits, empirical impact evaluations of adjudicative tribunals are not being conducted. This absence of assessment efforts is most likely attributable to the various challenges facing anyone who embarks on undertaking such a project. In the context of health adjudicative tribunals, these obstacles can be divided into three categories: (A) complexity in the health system; (B) methodological complications; and (C) legal barriers.

\section{A. Challenges with Complexity in the Health System}

Empirically evaluating the impact of any adjudicative tribunal is a naturally difficult enterprise as it requires the body's various effects to be isolated from the larger social context within which it operates. This is no doubt complicated for tribunals in every sector because their activities are usually only indirectly related to their existential goals. This challenge, however, may be further exacerbated in the health context due to its overwhelming complexity.

Indeed, health systems are increasingly being recognized as complex adaptive systems that are multi-layered, non-linear and highly sophisticated. They consist of

50 Mello \& Zeiler, supra note 3; N. Jones et al., "Working Paper 300: Improving Impact Evaluation Production and Use" (London: Overseas Development Institute, 2009) online: <http://www.o-di.org.uk/resources/download/3177.pdf>.

51 World Health Organization, World Report on Knowledge for Better Health (Geneva: World Health Organization, 2004) online: WHO < http://www.who.int/r-p-c/meetings/world_report_ knowledge_for_better_health.pdf $>$; K. Chalkidou et al., Comparative Effectiveness Research and Evidence-Based Health Policy: Experience from Four Countries. 200987 Milbank Quarterly 339. Online: Milbank <http://www.milbank.org/quarterly/milq_87_2-final-chalkidou.pdf>. 
countless sub-systems with immeasurable independent actors, established policies, zealously guarded interests, entrenched professional "silos" and divergent cultures that can all influence each another and even alter their external environments. This web of elements, and the unpredictable interactions among them, ensures that conventional mechanistic or "cause-effect" conceptualizations of the health system are inaccurate and oversimplifications of its complex dynamics. ${ }^{52}$

While scientific knowledge has been greatly advanced by breaking big questions into smaller ones that can be observed, analyzed and understood through rational deduction, this process is severely limited when the studied phenomenon or intervention is located within a system whose constitutive parts are not independent, constant nor predictable. The fact that the health system exhibits characteristics of distributed control, co-dependence and nesting of smaller systems within other larger systems further aggravates this challenge and makes it difficult to fully examine adjudicative tribunals without reference to other actors and institutions (such as adjudicators, staff, government policymakers, regulatory colleges, relevant expert panels, the traditional court system and the public). Isolating and attributing impact is further problematized by the fact that health-related adjudicative tribunals serve diverse functions according to various players within completely different contexts. ${ }^{53}$

\section{B. Challenges with Research Methodology}

Yet in addition to the daunting barriers of evaluating adjudicative tribunals caused by health system complexity, there are further methodological barriers associated with such an undertaking. The primary challenge, as highlighted above, is that simple research designs cannot be used to isolate adjudicative tribunals and elegantly locate cause-effect relationships between them and their goals. But above and beyond the various explanations illuminated by the complexity perspective is the fact that efforts of adjudicative tribunals are only indirectly related to their goals. Indeed, health services themselves only partially help meet their goal of improved health for people. Any legal, regulatory or oversight "intervention" that serves to better structure these services would be even further removed from their ultimate goals. Empirical impact studies of such interventions must be expertly designed to account for this complexity.

However, even if simple methods did exist to observe the relationship between adjudicative tribunals and their goals, there is currently a lack of clear evaluative criteria against which particular adjudicative tribunals can be measured. This is because their goals are not easily articulated and have thus not been defined with adequate precision - if defined at all. Desired outcome measures are consequently absent which ensures that suitable quantitative and/or qualitative research methodologies cannot be matched to them. This problem, however, cannot simply be overcome by brainstorming possible goals of adjudicative tribunals. Indeed, the existential purpose of these bodies may change and evolve over time with new legislators, government policymakers, adjudicators and tribunal staff who can each

52 B. Zimmerman, P. Plsek \& C. Lindberg, Edgeware: Insights from Complexity Science for Health Care Leaders (Irving, Texas: VHA Inc., 1998)

53 P.E. Plsek \& T. Greenhalgh (2001) "Complexity Science: The Challenge of Complexity in Health Care" 323 Brit Med J 625. 
contribute towards a shift in the focus and priority of their operations over time. ${ }^{54}$ Various community stakeholders may also perceive the role of a particular adjudicative tribunal in their sector very differently depending upon their own mandate, ideological perspective and unique vantage point. While reference to a tribunal's enabling statute may be informative in crafting an outcome measure, it is not always decisive. In the case of HPARB, legislative provisions suggest this body was created to ensure effective regulation of the health professions in the public interest, ${ }^{35}$ yet this goal is not easily measurable. Indeed, the ability to empirically evaluate a complex intervention like a health-related adjudicative tribunal depends upon having a desired outcome that is observable and testable against a null hypothesis.

A desire to empirically "prove" cause-effect relationships between adjudicative tribunals and a particular outcome is also complicated by the impossibility of randomly allocating potential users of existing tribunals into groups that either receive or do not receive their services. Randomized controlled trials - the most rigorous of discrete empirical evaluations ${ }^{56}$ - assess the effect of an intervention on a test population in comparison to a theoretically identical population. This method, however, requires a properly-constituted (i.e., randomized) and adequately-sized (i.e., large) control group with both known and unknown confounding factors evenly distributed between them in order to isolate the impact of tribunal services and measure it against a benchmark. Non-randomized retrospective evaluations comparing users of tribunals to non-users (or the situation of the general public in jurisdictions with and without comparable tribunals) may not be an ideal solution to this challenge as this creates a situation where user-status and outcomes are measured at the same time. This prevents efforts to control for confounding factors which in turn extinguishes the possibility of making causal determinations. ${ }^{57}$

A penultimate methodological challenge for conducting external impact evaluations of health-related adjudicative tribunals is that there are few examples of past efforts upon which to emulate. As previously mentioned, many empirical studies have examined the internal processes of tribunals, but none could be found that focused on their societal impact. This is exacerbated by the dearth of obvious empirical data sets which can be analyzed and from which potential evaluators can draw. ${ }^{58}$ Whereas hospitals may be able to compare their patient population and its outcomes to those from neighbouring hospitals, adjudicative tribunals are not likely in a position to continually collect data about their past users nor compare this information to existing data sets from the same region or other jurisdictions.

54 For example, the evolution of Ontario's Health Professions Appeal and Review Board over a period of 40 years was documented in the tribunal's formal submission to the Health Professions Regulatory Advisory Council regarding interprofessional collaboration among health colleges and professionals. Health Professions Appeal and Review Board, Recommendations to Health Professions Regulatory Advisory Council. (Toronto: Health Professions Appeal and Review Board, 2008). online: HPARB <http://www.hprac.org/en/projects/resources/hprac-1457May30HPARB.pdf $>$.

55 Regulated Health Professions Act, 1991, S.O. 1991, c. 18, s. 3.

56 GRADE Working Group, “Grading Quality of Evidence and Strength Recommendations”(2004)328 Brit Med J. Available online: BMJ < http://www.bmj.com/cgi/content/full/328/7454/1490> (accessed on 10 April 2009).

57 Mello \& Zeiler, supra note 3.

58 Ibid. 
Finally, the identity and background of the researcher(s) evaluating the impact of an adjudicative tribunal must also be considered. While the goal of empirical study is to avoid bias and ideological assumptions, every researcher brings a particular matrix of perspective, orientation, experience and values to their work. Insiders, for example, may bring intuition and experiential judgment, while outsiders may bring independence, fresh eyes and objectivity.

\section{Legal Barriers}

As institutions that function within both the health and legal systems, healthrelated adjudicative tribunals must also overcome the realities of the legal sector that may not be particularly nurturing for empirical impact evaluations. For example, legal actors are often focused more on achieving due process, transparency and good governance than specific societal outcomes (like improved health status which is the goal of direct clinical health care). Excellent process in the legal world is often thought to be the most likely way to achieve the best outcome, without much attention to the actual substantive benefits or costs to which an excellent process might give rise.

There is also, appropriately, a much greater concern for maintaining independence and avoiding any apprehension of bias. Like impartiality, independence is a common law right of procedural fairness enjoyed by parties who come before administrative bodies in common law jurisdictions (including Canada, United States, United Kingdom, Australia and New Zealand). In Canada, independence for adjudicative tribunals is based on the categories of judicial independence identified by the Supreme Court of Canada in Valente $v$. The Queen (i.e., security of tenure, financial independence and administrative independence over adjudicative matters $)^{59}$ and applied to administrative bodies in Canadian Pacific Ltd. v. Matsqui Indian Band - albeit in a more flexible and contextually sensitive manner. ${ }^{60}$

Respecting this independence of adjudicative tribunals will naturally influence the process and content of any evaluation in multiple ways. For example, independence suggests that governments should refrain from evaluating tribunals' substantive decisions lest reasonable observers apprehend that tribunals may adjust their decision-making to align with what the government of the day perceives as "successful." Similarly, it may also be difficult for a tribunal to establish evaluative criteria or outcome measures for itself as this might lead a reasonable observer to conclude that the tribunal may pursue these goals at the expense of fairness to the parties. This concern for independence even questions the extent to which tribunals' staff and members can be directly involved in any evaluation for fear of influencing or interfering with their services that must remain neutral at all times. Contrary to encouraging self-evaluation as is common within the health sphere, the legal environment may actually discourage adjudicative tribunals from assessing their own

59 Valente v. The Queen (1985), 24 D.L.R. (4th) 161 (S.C.C.).

60 Canadian Pacific Ltd. v. Matsqui Indian Band (1995), 122 D.L.R. (4 $\left.{ }^{\text {th }}\right) 129$ (S.C.C.). It should be noted that these standards of independence that are relevant in the adjudicative tribunal context are only a common law right which may be displaced by statute, unlike judicial independence which is a constitutional principle. See Ocean Port Hotel v. British Columbia, 2001 SCC 17. 
external impact, especially since such undertakings are not explicitly part of their statutory mandates. ${ }^{6}$

Finally, as recently highlighted by the Nuffield Inquiry on Empirical Legal Research, the legal academy also suffers from a dearth of empirical competence and capacity to conduct such studies. ${ }^{62}$ While the field of empirical health law scholarship has recently grown exponentially, ${ }^{63}$ it is generally accepted that current capacity is inadequate and that it may further diminish over time. Empirical legal methodologies are also not generally recognized to be as prestigious within the academic community as traditional doctrinal investigations. ${ }^{64}$ The pervasive culture of deference to experts and authority must further diminish the perceived value of objective empirical work and weaken any apparent need for more rigorous research that is higher on the hierarchy of evidence. ${ }^{65}$ Again, the focus on elements of process (e.g., bias and independence) rather than impact (e.g., judicial decisions) as indicator of quality and performance must also deter legal scholars from conducting work in this area such that target outcomes are less likely to be assessed.

\section{REASONS FOR OPTIMISM}

However, despite the challenges faced by potential evaluators of adjudicative tribunals, there is reason for optimism: each of the various identified barriers can be overcome and have indeed been circumvented in similar evaluations. For example, as previously mentioned, many empirical evaluations have been conducted that focus on the internal operations of these bodies. A major literature review in 2007 highlighted much of the work that has been conducted and published in this area. ${ }^{6 \sigma}$ Yet in addition to these studies, empirical evaluations have also been undertaken to assess the external impact of similarly-functioning specialty courts that operate within the judicial system. A systematic review of the research evidence has even been conducted on the societal impact of at least one type of these judicial organs. ${ }^{67}$

Indeed, methodologically, there may be much to learn from external impact evaluations of specialist courts in the judicial sector. ${ }^{68}$ For example, "drug courts" have been extensively evaluated in the United States and in other jurisdictions

61 On the other hand, a study which expresses respect for the adjudicative independence of tribunals will likely have greater credibility and attract broader "buy in" than a study which is perceived as inconsistent with it.

62 H. Genn, M. Partington \& S. Wheeler, Nuffield Inquiry on Empirical Legal Researcb: Law in the Real World: Improving our Understanding of How Law Works: Final Report and Recommendations (London: Nuffield Foundation,2006) Online: UCL<http://www.ucl.ac.uk/laws/socio-legal/empirical/docs/inquiry_ report.pdf $>$.

63 Mello \& Zeiler, supra note 3.

64 Genn, Partington \& Wheeler, supra note 62.

65 GRADE Working Group, supra note 56.

66 M. Partington, E. Kirton-Darling \& F. McClenaghan, Empirical Research on Tribunals: An Annotated Review of Research Published between 1992 and 2007 (London: Administrative Justice and Tribunals Council, 2007) Online: AJTC < http://www.ajtc.gov.uk/docs/EmpiricalResearch.pdf>.

67 D.B. Wilson, O. Mitchell \& D.L. Mackenzie, "A Systematic Review of Drug Court Effects on Recidivism" (2006) 2 Journal of Experimental Criminology 459.

68 J. Plotnikoff \& R. Woolfson, Review of the Effectiveness of Specialist Courts in Other Jurisdictions. DCA Report Series, No. 3/05. (London: UK Department for Constitutional Affairs, 2005) Online: DCA

< http://www.dca.gov.uk/research/2005/3_2005.pdf>. 
regarding their ability to increase treatment rates, lower criminal recidivism, and enhance cost-effectiveness of prosecution. ${ }^{69}$ Domestic violence courts and community courts have similarly been assessed for compliance, cost-effectiveness, conviction rates and public perception, and mental health courts have been comprehensively examined for reducing criminal violence, enhancing community safety, conserving fiscal resources and improving clinical outcomes. However, it must be recognized that the context within which these judicial bodies operate is very different from that of health-related administrative tribunals. Not only are they part of the judiciary rather than the executive branch of government, but their existential goals are usually related to diverting complex or special cases from traditional courtrooms rather than supporting the infrastructure of a completely different system (like that of health). Empirically tracking desired outcomes like cost-savings and reduced reoffending rates will naturally be easier in this context when the intervention or service is more directly related to its goal. Yet, alternatively, it may actually be more difficult for these judicial organs to evaluate themselves due to their strict separation from the executive (which has the financial resources to fund such an undertaking) and the likelihood of them to zealously guard their independence.

The possible range of empirical legal research methodologies that can be used in evaluating health-related adjudicative tribunals may benefit from earlier studies. For example, Mello and Zeiler describe the diversity and comparative advantages of various empirical approaches that have been taken by scholars in the health law field to address issues as wide-ranging as medical malpractice reform and motor safety laws. ${ }^{70}$ And on the use of randomized controlled trials, for which these two scholars are less optimistic, Pleasence provides an account of such an undertaking in the United Kingdom, highlights the many technical, practical and ethical barriers that were faced, and suggests ways to overcome them in the future. ${ }^{71}$

\section{OPPORTUNITIES FOR MOVING FORWARD}

There are several developments converging on the importance of evaluation. First, there is a wave of interest in enhancing accountability both in governmental and administrative settings. Second, and related to the first development, governments are increasingly attracted to legislative schemes which provide for greater transparency and oversight. In Ontario, for example, the recently enacted Adjudicative Tribunals Accountability, Governance and Appointments Act, 2009 requires a set of prescribed adjudicative tribunals (including HPARB and HSARB) to publish a set of "public accountability documents" which include a mandate and mission statement, a public consultation policy, a service standard policy, an ethics plan, and a member

69 Wilson, Mitchell \& Mackenzie, supra note 67; United States Government Accountability Office, Adult Drug Courts: Evidence Indicates Recidivism Reductions and Mixed Results for Other Outcomes (Washington DC: United States Government AccountabilityOffice,2005) online: GAO<http://www.gao.gov/ new.items/d05219.pdf>; B.L. Green et al., "Building the Evidence Base for Family Drug Treatment Courts: Results from Recent Outcome Studies" (2009) 6 Drug Court Review 53. Online: NDCI<http://www.n-d-c-i.org/sites/default/files/ncdc/DCR $\% 2 \mathrm{C} \% 20$ Vol. $\% 206 \% 2 \mathrm{C} \%$ $20 \mathrm{No} \% 202 . \mathrm{pdf}>$ ).

$70 \quad$ Mello \& Zeiler, supra note 3.

71 P. Pleasence, "Trials and Tribulations: Conducting Randomized Experiments in a Socio-legal Setting" 2008) 35 J L \& Soc'y 8. 
accountability framework. The consultation plan must describe whether and how the tribunal will consult with the public when it is considering changes to its rules or policies. The service standard policy must set out the standards of service that the tribunal intends to provide and a process for making, reviewing and responding to complaints about the tribunal's service. The member accountability framework must contain a description of the functions of the members of the tribunal and a description of the skills, knowledge, experience, other attributes and specific qualifications required of a person to be appointed as a member of the tribunal. A code of conduct must also be established for the members of the tribunal. Finally, the Act also requires adjudicative tribunals to prepare governance accountability documents, including a memorandum of understanding, a business plan and an annual report. While these "public accountability documents" do not necessary provide the data necessary to conduct a complete evaluation of a tribunal, they help foster a culture of evaluation through tracking data, identifying benchmarks and engaging in strategic planning.

In order to determine the data which will be helpful in evaluating tribunals such as HPARB and HSARB, potential evaluators must also thoughtfully consider both the target audience of their research and the overall goal that their particular healthrelated adjudicative tribunal is expected to help achieve, and then identify the most important targeted outcomes that are relevant to the audience and important for the goal's fulfillment. ${ }^{72}$ When such outcomes cannot directly be measured, as may often be the case, evaluators must identify strong surrogate endpoints which are measurements that reflect important outcomes even if they are of indirect or diminished practical importance. Performance indicators can then be developed followed by the corresponding methodologies for tracking changes to them.

In the case of Ontario's health-related adjudicative tribunals, both HPARB and HSARB may describe their overall goal as contributing to the health of Ontarians by enhancing decision-making within the health system. If government officials are the evaluation's intended audience, targeted outcomes could include: (1) confidence in the health system, (2) equity, justice and fairness in health decision-making, (3) strengthened health system institutions, and (4) better health services and patient safety via enhanced regulation and oversight. Since these outcomes would be nearly impossible to measure directly, surrogate endpoints can be developed and could possibly include: (1) access to adjudicative mechanisms for dispute resolution, (2) perceived legitimacy of adjudicative decisions, (3) satisfaction with adjudicative services, (4) perceived fairness and legitimacy of adjudicative services, (5) changed conduct of health system institutions and decision-makers, (6) establishment or expansion of support mechanisms for primary health decision-makers, (7) improved oversight of primary health decision-makers leading to better health outcomes, (8) better diagnostic and treatment decisions by primary health decision-makers, and (9) respect among stakeholders for the tribunal's oversight function. Performance indicators and their corresponding empirical methodologies could then range from the public's awareness for the tribunal's existence to the perceived concern among primary health decision-makers that their decisions will be reversed.

Once a system of empirical observation is in place, potential evaluators can establish benchmarks according to which they can track and assess performance.

$72 \quad$ S.O. 2009 c.33 schedule 5. 
Such comparative points of measurement can be drawn from thoughtful consideration, aspirational goals of leaders, expert judgments on what is possible, data from similar tribunals in other jurisdictions (i.e., comparative analysis), or previous empirical observations from the same tribunal (i.e., interrupted time-series analysis.

\section{CONCLUSION}

In summary, adjudicative tribunals serve an essential function within the health sector, yet their contributions and impact on the delivery of health services and society in general are not usually evaluated empirically. A focus on evaluation may enhance tribunals' capacity to engage in continuous quality improvement efforts, enhance the public's confidence, and maximize their societal impact. More broadly, a focus on empirical evaluation extends the reach of administrative law to the norms and means of administrative adjudication, and beyond the legal doctrines considered by tribunals or the courts which supervise them. In our view, understanding the significance and implications of these doctrines requires situating them in institutional and policy contexts. For administrative law, in short, it ought to matter whether administrative justice is or is not being realized. 